\title{
Maturation and Seasonal Discharge Pattern of Ascospores of Anisogramma anomala
}

\author{
J. N. Pinkerton, K. B. Johnson, J. K. Stone, and K. L. Ivors
}

First and fourth authors: USDA-ARS, Horticultural Crops Research Laboratory, 3340 N.W. Orchard Avenue, Corvallis, OR 97330; and second and third authors: Department of Botany and Plant Pathology, Oregon State University, Corvallis 97330-2902.

Accepted for publication 23 July 1998.

\begin{abstract}
Pinkerton, J. N., Johnson, K. B., Stone, J. K., and Ivors, K. L. 1998. Maturation and seasonal discharge pattern of ascospores of Anisogramma anomala. Phytopathology 88:1165-1173.

Maturation and release of ascospores of Anisogramma anomala were monitored over a 6-year period (1988 to 1995) in European hazelnut orchards located in western Oregon. Perithecia of A. anomala were dissected from stromata collected monthly from September to May to determine spore maturation. Spore maturation began in late summer; by January, $>90 \%$ of the spores were morphologically mature. Similarly, both the number of mature ascospores per perithecium and the proportion of ascospores that germinated increased through autumn. After January, the number of spores per perithecium declined until May, when few viable spores remained. Each of the 6 years, rain catch-type spore traps were placed under cankers in diseased trees from 15 September to 30 June. Based on spore collection periods of 1 to 4 weeks, three patterns for the seasonal
\end{abstract}

ABSTRACT release of A. anomala ascospores were observed: in the 1988-1989 season, $>80 \%$ of the seasonal ascospore release occurred between September and January; in the 1989-1990 season, 32 to $42 \%$ of the seasonal ascospore release occurred after mid-April; and in the other 4 years, monthly releases of ascospores were relatively uniform over the 9-month seasonal period. Timing and amount of precipitation were the most important variables accounting for the differences among the yearly patterns of ascospore release. Over all years and sites, the cumulative proportion of total ascospores collected in each orchard was highly correlated $\left(R^{2}=0.90\right)$ with cumulative precipitation. This relationship was confirmed in mist chamber experiments. A regression model was developed relating cumulative ascospore release to cumulative hours of precipitation. The model provides an estimate of the proportion of ascospores remaining to be released after budbreak, which coincides with the period of highest susceptibility to infection.

Additional keywords: aerobiology, Corylus avellana.
Eastern filbert blight is a devastating disease of European hazelnut (Corylus avellana L.) caused by the pyrenomycete Anisogramma anomala (Peck) E. Müller in E. Müller \& Arx. Since the introduction of A. anomala into southwest Washington 30 years ago (2), the pathogen has moved south into Oregon's Willamette Valley, where European hazelnut is produced commercially on 12,000 ha $(8,19)$. In Oregon, most of the orchards initially diseased have been destroyed, and the portion of orchards infested with the pathogen continues to increase annually.

A. anomala infects immature hazelnut shoots in the spring following budbreak $(11,23)$. Over the summer, the pathogen colonizes cambium, phloem, and secondary xylem (6) without producing apparent symptoms of disease. In April of the year after initial infection, a perennial canker is formed. Branches are girdled as the cankers expand laterally over a period of 1 to 5 years (7). On highly susceptible cultivars, the entire canopy often dies back in 4 to 5 years if not protected with fungicides; moderately susceptible cultivars become unproductive after 8 to 12 years $(10,16)$.

Gottwald and Cameron (6) documented the development of the ascostromata and ascospores of A. anomala. Rows of elliptical stromata form within cankers, each containing 40 to 60 perithecia per stroma that mature by late summer. Asci are produced continually through autumn until perithecial expansion is restricted by neighboring perithecia or stromal walls. The release of mature ascospores begins as early as September and extends through late spring.

Corresponding author: J. N. Pinkerton; E-mail address: pinkertj@ava.bcc.orst.edu

Publication no. P-1998-0827-01R

This article is in the public domain and not copyrightable. It may be freely reprinted with customary crediting of the source. The American Phytopathological Society, 1998.
Recently, we examined the release of ascospores of A. anomala as affected by environmental parameters measured during the period of host susceptibility, i.e., March to June (18). Ascospores were collected by volumetric spore traps when the surfaces of branches were wet from precipitation, but not when branches were dry or wet only from dew. The rate of ascospore discharge increased with increasing duration of rain, reaching a maximum between 5 and $12 \mathrm{~h}$ after the onset of precipitation. Within each season, the number of ascospores collected declined significantly from March to May. Under Oregon conditions, Gottwald and Cameron (8) observed that many, if not most, ascospores of A. anomala are released during autumn and winter, when the host is not susceptible to infection.

Seasonal variation in conditions affecting ascospore release and survival may alter the proportion of ascospores that are available to cause new infections. Ascospores of A. anomala are relatively short lived (3 to 5 days) (11). Variables that regulate ascospore availability include the number of ascospores produced in each perithecium, the rate of ascospore maturation, and the timing and intensity of environmental conditions that trigger spore release. Understanding how these variables, precipitation in particular, influence the relative number of ascospores remaining to be released after hazelnut becomes susceptible to infection may provide useful information to growers who use fungicides to protect their trees from new infection. The objective of this study was to develop a quantitative model of seasonal maturation and release of ascospores of $A$. anomala based on perithecial productivity and phenology and on the environmental conditions.

\section{MATERIALS AND METHODS}

Ascospore development and maturation. During the first week of each month from September to June of 1990 through 1995, 15 to 
20 hazelnut branches ( 1 to $2 \mathrm{~cm}$ in diameter, cultivars Barcelona or Ennis) with 6- to 15-month-old eastern filbert blight cankers were collected from orchards located in Multnomah County, OR. Branches were trimmed into $15-\mathrm{cm}$ segments, wrapped in wet paper toweling, enclosed in doubled polyethylene bags, and frozen at $-20^{\circ} \mathrm{C}$ until examination. Three intact perithecia from randomly selected stromata on each of eight branch segments from each monthly collection were removed for examination. Dissected perithecia were fixed in boiling water for $1 \mathrm{~min}$, transferred to a drop of $2 \%$ formaldehyde on a glass slide, crushed and mixed using a forceps, and covered with a cover glass $(3,26)$. Stage of maturity of 100 asci from each perithecium was classified as (i) undifferentiated without ascospores, (ii) immature with ascospores beginning to differentiate, and (iii) mature with ascospores fully developed. In addition, maturity of asci was classified by sectioning excised stromata from monthly collections made between September 1990 and May 1991. Excised stromata were dehydrated in an acetone series and infiltrated and embedded in Spurr's resin (22). Sections ( 3 to $4 \mu \mathrm{m})$ of stromata were cut with a glass knife and stained with $0.25 \%$ toluidine blue (24). Sections were viewed at $\times 400$ with bright field microscopy.

Monthly estimates of the number of ascospores per perithecium and the ascospore germination rate were determined by sampling five additional perithecia from each of the eight stromata used to evaluate maturity. To minimize contamination in the germination assays, perithecia from each stroma were dipped in $95 \%$ ethanol for $5 \mathrm{~s}$, and then crushed in a Syracuse watch glass (PGC Scientific, Gaitherburg, MD) containing rifampicin (10 ppm) in sterile distilled water. Ascospores were mixed and counted with the aid of a hemacytometer. Ascospore suspensions were then adjusted to $5 \times$ $10^{4}$ ascospores per $\mathrm{ml}$ with sterile deionized water and placed on sterile cellulose nitrate membranes (20). Membranes were placed on the surface of a modified Murashige and Skoog agar (24), incubated for 5 days at $20^{\circ} \mathrm{C}$ in the dark, and then stained for $24 \mathrm{~h}$ in a drop of $0.05 \%$ trypan blue in lactoglycerol (17). Germination, i.e., length of germ hyphae greater than one-half the width of the spore ( 3 to $4 \mu \mathrm{m}$ ), for 200 ascospores from each stromata was evaluated at a magnification of $\times 400$.

Seasonal ascospore release. From 1988 to 1994, ascospores of A. anomala were collected with rain catch-type spore traps (1) placed in diseased hazelnut trees in orchards located in Clackamas and Multnomah counties, OR. Each season, the traps were operated continuously from 15 September to 30 June. The 15 September initiation date was chosen because it preceded the start of the autumn and winter rainy season. The traps were designed to collect

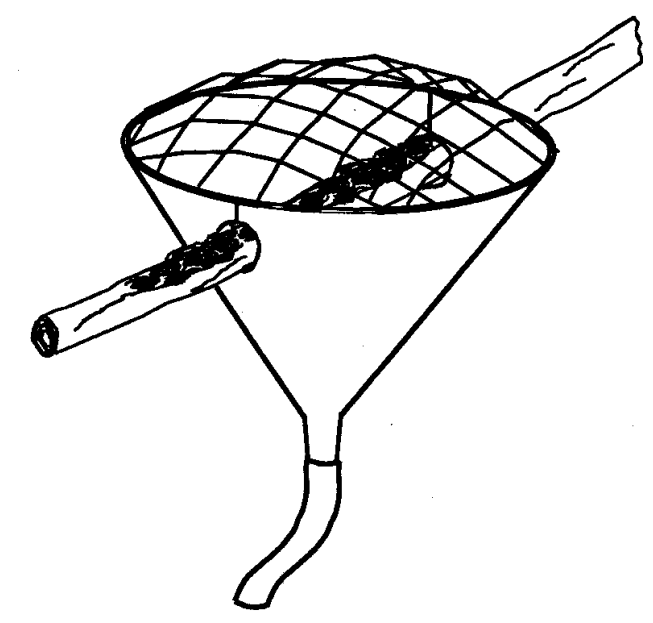

Fig. 1. Rain catch-type spore trap used to collect ascospores of Anisogramma anomala in European hazelnut trees. A 13-cm length of a cankered branch was placed within the trap. The trap drained through a vinyl tube into 2-liter bottles that were replaced at regular intervals. spores beneath sporulating cankers in hazelnut canopies. For the first five seasons, the spore traps were constructed from $15-\mathrm{cm}$ diameter plastic funnels (Fig. 1). Two opposing holes $2 \mathrm{~cm}$ in diameter were drilled $2 \mathrm{~cm}$ below the lip of the funnel, and the plastic was cut from the funnel lip into the holes. A diseased branch was inserted through the cut into these holes such that a $13-\mathrm{cm}$ length of a 6- to 15-month-old canker ran across the funnel opening. Intersections of the branch and funnel were secured with a silicon sealant. A vinyl hose ran from the funnel spout into a 2-liter plastic bottle that contained a preservative $\left(50 \mathrm{ml}\right.$ of a $20 \% \mathrm{CuSO}_{4}$ solution). Five to ten funnel-type traps were placed in one or two orchards each season: orchard Z (in Multnomah County) in 19881989, orchards J (in Clackamas County) and Z in 1989-1990 and 1990-1991, orchard K (in Clackamas County) in 1991-1992, and orchards K and T (in Clackamas County) in 1992-1993. Branches within 30 to $40 \mathrm{~cm}$ of the traps were pruned to slightly increase the exposure of the selected canker to rain. For the 1993-1994 season, five gutter-type spore traps constructed from a 3-m-length PVC pipe (16) were placed under diseased trees in a fifth orchard (D) located in Clackamas County. Height of the traps was approximately $1 \mathrm{~m}$ above the ground; the traps were positioned at a slight angle to drain into a plastic bottle.

Collection bottles were removed and replaced weekly during the first three seasons. Bottles were replaced every other week from September 1991 through February 1992, and then weekly until June 1992. The collection period was every other week for all of the 1992-1993 season. For the 1993-1994 season, the collection period was lengthened to once a month between September and February, and then to every other week through June. Collected rain was processed by measuring the volume and then stirring and filtering a subsample through a $20-\mu$ sieve, which removed most debris but not ascospores of $A$. anomala $(5 \times 10 \mu)$. Because the concentration of ascospores in collected rain varied over the season, the size of the subsample processed was based on the concentration of spores in the previous sample. For example, rain samples from fall and winter usually had high concentrations of spores; thus, a 10-ml subsample diluted 1:10 with tap water was sufficient to estimate ascospore concentration. Collections from late winter to late spring required processing of 50 - to $200-\mathrm{ml}$ subsamples with no dilution because of the lower numbers of spores released during that period. A 50-ml volume of the subsample was filtered through a gridded, cellulose nitrate filter $(25 \mathrm{~mm}$ in diameter with $0.8-\mu$ pore size; Whatman International Ltd., Maidstone, England) held in a syringe-type holder (model 4320; Gelman Scientific, Ann Arbor, MI). Filters holding ascospores were stained in $0.05 \%$ trypan blue in lactoglycerol for $24 \mathrm{~h}$, and then dried by blotting (20).

Stained filters were mounted on glass slides, and the number of ascospores in five filter grids ( $12 \%$ of surface area) was counted under a bright field microscope $(\times 400)$. Ascospores of A. anomala were distinguished from other spores of similar size by their distinctive apical cap cell (6). Five additional grids were examined if there were large differences in ascospore number among the initial counts. The number of ascospores collected in a trap was estimated from the number of spores on each filter, the volume of rain collected, and the dilution of the subsample. At the end of the season, data for each trap and sampling period were summarized as the cumulative proportion of the total ascospore release $\left(A_{\text {cum }}\right)$. The quantity, $A_{\text {cum }}$, was computed as the sum of the proportion of the total number of spores collected during each sampling period with the values from all preceding periods. Values of $A_{\text {cum }}$ were averaged for all traps from the same orchard and season.

Meteorological conditions at each site were recorded with dataloggers (CR21X; Campbell Scientific, Inc., Logan, UT) programmed to read sensors at 5-s intervals and to record averages at 1-h intervals. The dataloggers were equipped with temperature and relative humidity sensors (model 207; Phys-Chem Scientific, New York) and a tipping-bucket rain gauge (model TE 525; Texas Electronics, Dallas). Over the 6-year period of the study, this equipment 
malfunctioned occasionally. In these instances, data were substituted from National Weather Service stations at Gresham or Portland, OR, which were located 10 to $20 \mathrm{~km}$ from the orchard sites. The amount of precipitation $(\mathrm{mm})$ and the number of hours with precipitation $(>0.25 \mathrm{~mm} / \mathrm{h})$ also were summarized as cumulative variables beginning from 15 September. Mean daily temperature was summarized as cumulative degree-days (base $5^{\circ} \mathrm{C}$ ) from 15 September. The $5^{\circ} \mathrm{C}$ base was chosen because $A$. anomala requires temperatures above this value for the germination of ascospores and hyphal growth (17).

Laboratory experiments on ascospore release. The effect of temperature and wetness duration on the release of A. anomala ascospores from cankered branches was studied in plastic-walled mist chambers that had dimensions of $0.3 \times 0.3 \mathrm{~m}$ by $0.4 \mathrm{~m}$ in height. A solenoid valve and nozzle (model D1; Spraying Systems Inc., Wheaton, IL) located at the top of the chamber produced a fine mist $(500 \mathrm{ml} / \mathrm{min})$ for $15 \mathrm{~s}$ once every $30 \mathrm{~min}$; this interval maintained constant wetness on cankered branches. Mist chambers were placed inside growth chambers set to 5,10 , or $15 \pm 1{ }^{\circ} \mathrm{C}$. The temperature of the water supply was equilibrated to the chamber temperature by drawing it through $8 \mathrm{~m}$ of 1 -cm-diameter vinyl tubing coiled inside the chamber. Each growth chamber had a 12-h light/dark cycle. Misted water that had run over cankered branches was collected in traps constructed of 3.8-cm-diameter $\times 0.4-\mathrm{m}$ length PVC pipe. A $15 \times 3$-cm-wide opening was cut midway along the pipe. The pipe was capped on both ends and drained by means of a vinyl tube at one end. Four traps were placed in each chamber, positioned horizontally on a slight angle to drain through the tube into a collection bottle. Misted water not collected by the traps was drained continuously from the chamber and discarded.

Experimental material for two of three spore release experiments consisted of 9-month-old eastern filbert blight cankers on 1-cmdiameter branches that were collected from a diseased orchard in November. Branches were stored frozen $\left(-20^{\circ} \mathrm{C}\right)$ and used in experiments within 4 months after collection. To begin an experiment, branches were cut to 15 -cm-length segments bearing 20 to 40 stromata. A branch segment was positioned in the $15-\mathrm{cm}$ opening of each trap with the stromata oriented toward the mist nozzle. Branch segments were supported above the trap bottom by rubber washers placed on the ends. Collection bottles were replaced every 5 days; $50 \mathrm{ml}$ of $5 \% \mathrm{CuSO}_{4}$ was added to the bottles at the beginning of each collection period. The ascospore concentration in the collected effluent was quantified as described above. The first experiment compared the effect of three temperatures $\left(5,10\right.$, and $\left.15^{\circ} \mathrm{C}\right)$ on the rate of ascospore release under conditions of continuous wetness. The second experiment compared continuous and discontinuous wetting of the canker at temperatures of 5 and $15^{\circ} \mathrm{C}$. The discontinuous-wetting treatment was imposed by turning the intermittent-mist system on and off over a 5-day cycle. The experiments were continued until very few spores were being collected (77 to 90 days). As in the field study, ascospore counts from each collection period were converted to the cumulative proportion of the total number of ascospores collected in each trap $\left(A_{\text {cum }}\right)$. Both experiments were repeated once.

The third ascospore release experiment used cankers on live branches. Two-year-old potted hazelnut trees ('Barcelona') were inoculated by exposure in a diseased orchard (16). Twenty months following exposure, in November, mature cankers had formed. Funnel-type traps, similar to those used in the field studies, were placed under four cankers on each of four trees. Two trees were then placed in a growth chamber maintained at 5 or $20^{\circ} \mathrm{C}$; the trees were misted for $15 \mathrm{~s}$ every $30 \mathrm{~min}$ for 90 days. Spore collection bottles were changed every 10 days and processed as described above. An estimate of the number of spores per perithecium was determined at the beginning and at the end of the experiment. Estimates were determined by crushing three perithecia from a stroma from each canker on each tree and counting the number of spores. For this experiment, values of $A_{\text {cum }}$ were adjusted by the portion of ascospores that remained in the perithecia at the end of the experiment.
Data analysis. For the laboratory experiments, values of $A_{\text {cum }}$ were pooled among experimental replications and subjected to timeseries analysis of variance (ANOVA) to evaluate the effect of temperature (experiment 1,2, and 3 ) and misting regime (experiment 2) on spore release (PROC GLM, version 6.0; SAS Institute, Inc., Cary, NC). Fisher's protected least significant difference $(P \leq 0.01)$ was used to compare mean values of $A_{\text {cum }}$ among treatments on the same sampling date. For experiment 3 , the number of ascospore remaining in perithecia also was analyzed by ANOVA. A chi-square goodness-to-fit test was used to compare the similarity between cumulative spore release patterns observed in the lab experiments with a regression model derived from this negative exponential function, which is described below and predicts $A_{\text {cum }}$ based on the cumulative hours of precipitation.

Ascospore discharge model. Cumulative meteorological variables and values of $A_{\text {cum }}$ were pooled among orchards and subjected to cross-correlation analysis (PROC ARIMA; SAS Institute, Inc.), which is recommended for comparison of time-series data because the effects of both past and current data values are considered in the calculation of the correlation coefficient. Values of $A_{\text {cum }}$, either nontransformed or arcsine $\sqrt{x}_{x}$-transformed, also were regressed on the cumulative precipitation and degree-day variables using a stepwise, polynomial regression procedure. Subsequently, negative exponential models that described the relationship between arcsine $\sqrt{x}$-transformed cumulative proportional ascospore release and cumulative precipitation since 15 September were developed using a nonlinear regression procedure (PROC NLIN, Marquardt method; SAS Institute, Inc.). An arcsine $\sqrt{ } x$ transformation was used because the proportional data were not normally distributed. Initially, models were developed only with data from the first three seasons (1988 to 1991). Data from the last three seasons (1991 to 1994) were then plotted against the models, and chi-square tests were performed to determine if the functions developed from the 1988 to 1991 data differed significantly from the 1991 to 1994 data. Final models, relating $A_{\text {cum }}$ to the cumulative amount or cumulative hours of precipitation, were then developed by pooling the 1988 to 1991 data with the 1991 to 1994 data. These models represented nine orchards over 6 years. To further evaluate the final model for the cumulative amount of precipitation, values of predicted and observed $A_{\text {cum }}$ were compared at the time of budbreak, when hazelnut becomes susceptible to infection, and at 2, 4, 6, and 8 weeks after budbreak. The 2-week interval was chosen because it approximates the period of protection afforded by a protective fungicide application $(10,12)$. Predicted values of the cumulative proportion of the seasonal ascospore total were based on the environmental data measured in each orchard. Differences between the predicted and observed $A_{\text {cum }}$ were tabulated.

\section{RESULTS}

Ascospore development and maturation. By early September, $91 \%$ of asci within stromata of $A$. anomala were undifferentiated; immature ascospores were present in the remaining $9 \%$. Asci and ascospores matured through the fall, with the proportion of undifferentiated asci declining to zero by January. The percentage of asci with immature ascospores increased to a maximum of $66 \%$ in November and declined to $<10 \%$ after January. A few asci contained mature ascospores in October, but significant ascospore maturation did not occur until November (Fig. 2). By December, perithecial walls had darkened, and mature ascospores were present in $70 \%$ of asci. Greater than $90 \%$ of asci contained mature ascospores after January (Fig. 2). Sections through whole stromata showed that very small perithecia that remained immature were present at the stromal margins during most of the season. These sections also showed that most perithecia were collapsed and nearly empty by April. By May, the few ascospores remaining were all in perithecia located near the stromal margin. 
Mean number of mature ascospores per perithecium increased from September to January, declined through winter and spring, and approached zero by June of each year (Fig. 3). For the two hazelnut cultivars examined, similar patterns were obtained for the average number of ascospores per perithecium plotted as a function of month of the year, but on average, a perithecium from the highly susceptible cultivar Ennis contained about twice as many ascospores as a perithecium from the moderately susceptible cultivar Barcelona. Less than $0.5 \%$ of the ascospores collected from perithecia in September germinated when placed on a growth medium (Fig. 2). The germination rate increased to an average of $22 \%$ by November, but this value varied greatly ( 5 to $40 \%$ ) among orchards and seasons. Between December and April, the rate of ascospore germination among orchards, months, and seasons was relatively constant, averaging from 40 to $47 \%$.

Seasonal ascospore discharge. For most seasons, ascospores of $A$. anomala first appeared in spore traps between late September and late October, with the first large collections of ascospores (i.e., $>1 \times 10^{5}$ ascospores per trap) usually occurring in November (Fig. 4). Based on the relative timing of ascospore releases, three different seasonal patterns were observed over the 6 years of the study. In the 1988-1989 season, $70 \%$ of the total ascospores collected were released during a 3 -week period in November, which coincided with the first major rain storms of that autumn (Fig. 4A). Precipitation was recorded during $331 \mathrm{~h}$ that month, which produced extended periods of branch wetness, a condition conducive for the release of $A$. anomala ascospores (18). Conversely, for the two orchards sampled the following season (1989-1990), 33 and $55 \%$ of the spores were not released until after mid-April. These late-April releases occurred during a rainy period that was preceded by a 9-week period of unusually dry conditions (Fig. 4B). During the other four seasons, monthly patterns of ascospore release were relatively uniform between November and May (Fig. $4 \mathrm{C}$ to $\mathrm{F}$ ). The absolute number of ascospores collected varied among orchards and years, with means ranging from $2.3 \times 10^{6}$ to $3.2 \times 10^{7}$ ascospores per trap per season. Patterns of ascospore collections were similar among orchards sampled at the same time, but there was no apparent relationship between the total number of spores collected and the pattern of ascospore release for a specific season.

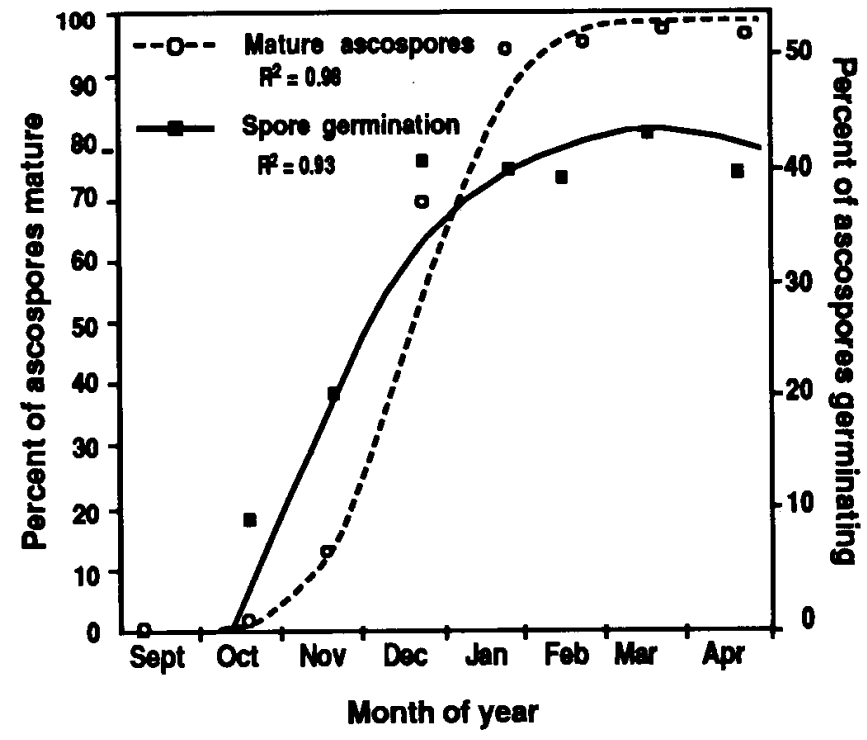

Fig. 2. Relative maturity of asci and the mean germination rate of ascospores of Anisogramma anomala collected monthly from European hazelnut trees located in Multnomah County, OR. Perithecia were collected from September to June in 1990 to 1995 . Maturity of asci was determined by microscopic examination of perithecia. Lines are polynomial functions fit to data: for ascospore maturation, $y=0.53 x^{4}-11.06 x^{3}+70.9 x^{2}-111.55 x+96.08$; and for germination, $y=1.64 x^{2}+21.48 x-24.98$.
Laboratory experiments on ascospore release. In mist chambers, conditions of continuous wetness for 77 days resulted in a pattern of ascospore release that was similar among temperature treatments (Fig. 5). Over the first $216 \mathrm{~h}$ of wetting, the proportion of total ascospores released per hour averaged $0.042,0.047$, and 0.053 for 5,10 , and $15^{\circ} \mathrm{C}$, respectively; after $216 \mathrm{~h}$ of continuous wetness, this hourly rate slowed to $0.0002,0.0001$, and 0.00005 for the respective temperature treatments. Spore release declined to negligible amounts (i.e., $<0.5 \%$ of total spores collected) after $1,560,1,272$, and $960 \mathrm{~h}$ at 5,10 , and $15^{\circ} \mathrm{C}$, respectively. ANOVA of $A_{\text {cum }}$ at the three temperatures over the duration of the experiment showed a significant $(P \leq 0.01)$ effect of temperature. In addition, after $2,160 \mathrm{~h}$ of continuous wetness, 26 and $66 \%$ more ascospores per stroma had been collected at 10 and $15^{\circ} \mathrm{C}$, respectively, than at $5^{\circ} \mathrm{C}$.

The effect of discontinuous wetting on cumulative ascospore release was evaluated by comparing only the wet hours of the wet/ dry cycle with the continuous-wetness treatment. The rate of ascospore release was reduced greatly by the discontinuous-wetness treatment at $5^{\circ} \mathrm{C}(P \leq 0.01)$ and to a lesser degree at $15^{\circ} \mathrm{C}$ (Fig. 6). The differential effect of temperature on the rate of spore release under conditions of continuous or discontinuous wetting was confirmed by a significant interaction between wetting treatment and temperature $(P \leq 0.01)$. As in the previous study, about $90 \%$ of total spores in the $15^{\circ} \mathrm{C}$ treatment were released by $300 \mathrm{~h}$ of wetness, but the rate of spore release was slower in the $5^{\circ} \mathrm{C}$ treatment, requiring about $1,100 \mathrm{~h}$ to attain a value of $A_{\text {cum }}>90 \%$ compared with $900 \mathrm{~h}$ in the previous experiment.

Patterns of ascospore release from cankers on attached branches were similar to those observed using detached branches, but the differences between the temperature treatments were more pronounced. After $240 \mathrm{~h}$ of misting at $20^{\circ} \mathrm{C}, A_{\text {cum }}$ averaged $97 \%$ of the number of spores in perithecia at the beginning of the experiment, but the value of $A_{\text {cum }}$ at $5^{\circ} \mathrm{C}$ was only $20 \%$ (Fig. 7). Similarly, after $2,160 \mathrm{~h},>99 \%$ of the spores had been released

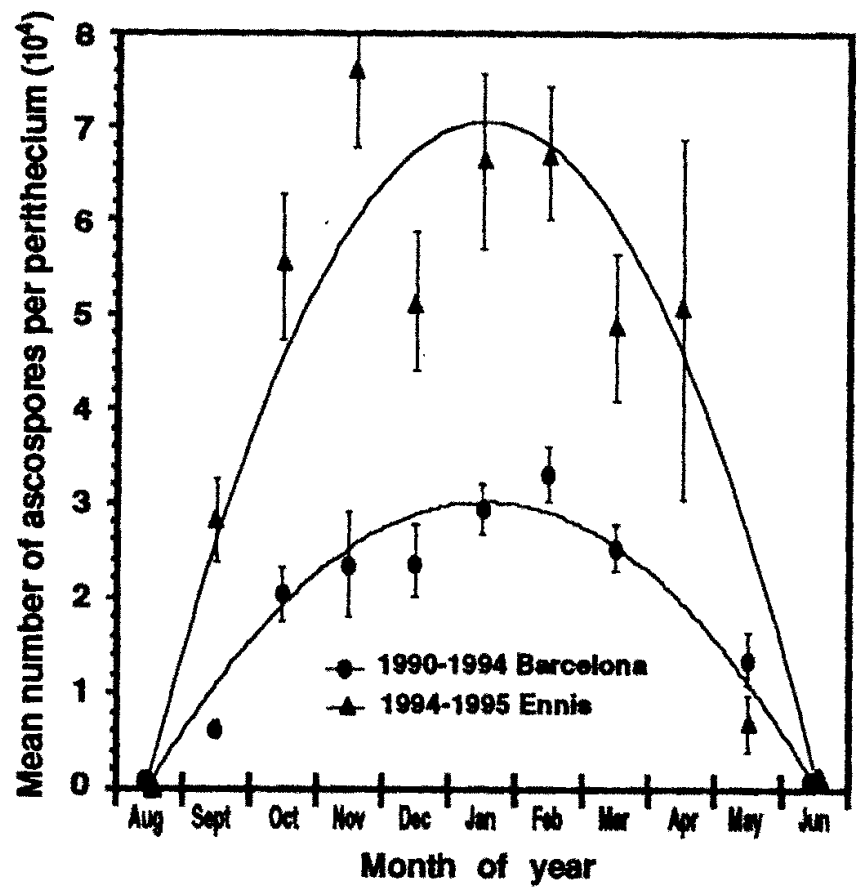

Fig. 3. Mean number of ascospores of Anisogramma anomala per perithecium on diseased hazelnut branches collected monthly in Multnomah County, OR, from August to June in 1990 to 1995 . The moderately susceptible cultivar Barcelona was sampled from 1990 to 1994, and the highly susceptible cultivar Ennis was sampled during the 1994-1995 season. Lines are second order polynomial functions fit to data: for 'Barcelona', $y=-1.19 x^{2}+1.46 x-$ $1.53\left(R^{2}=0.95\right)$; and for 'Ennis', $y=-2.77 x^{2}+3.19 x-2.33\left(R^{2}=0.88\right)$. Vertical bars denote standard deviation. 
at $20^{\circ} \mathrm{C}$, but only $50 \%$ of the initial number of spores were released at $5^{\circ} \mathrm{C}$.

Ascospore discharge model. Orchard data for the cumulative proportion of the seasonal ascospore total $\left(A_{\text {cum }}\right)$ was best correlated with the cumulative amount $(\mathrm{mm})$ of precipitation $(r=0.920$, $n=369$ ) and the cumulative hours of precipitation ( $r=0.913, n=$ 369) since 15 September, with the two precipitation variables being highly autocorrelated $(r=0.973, n=369)$ (Table 1$)$. $A_{\text {cum }}$ also was less correlated ( $r=0.803, n=369)$ with cumulative degree-days (base $5^{\circ} \mathrm{C}$ ) since 15 September. Forward stepwise, multiple regres- sion of $A_{\text {cum }}$ on cumulative precipitation, hours of precipitation, and degree-days resulted in an order of variable selection that corresponded with the ranking of the correlation coefficients (Table 1); the cumulative amount of precipitation was the only independent variable to add significantly $(P>0.01)$ to this model. According to a chi-square test, the negative exponential model developed with data from the first three seasons (1988 to 1991) was not significantly different $(P>0.05)$ from the model developed from data collected in 1991 to 1994 . Regression of the arsine $\sqrt{x}$-transformed values of $A_{\text {cum }}$ on the cumulative amount of precipitation

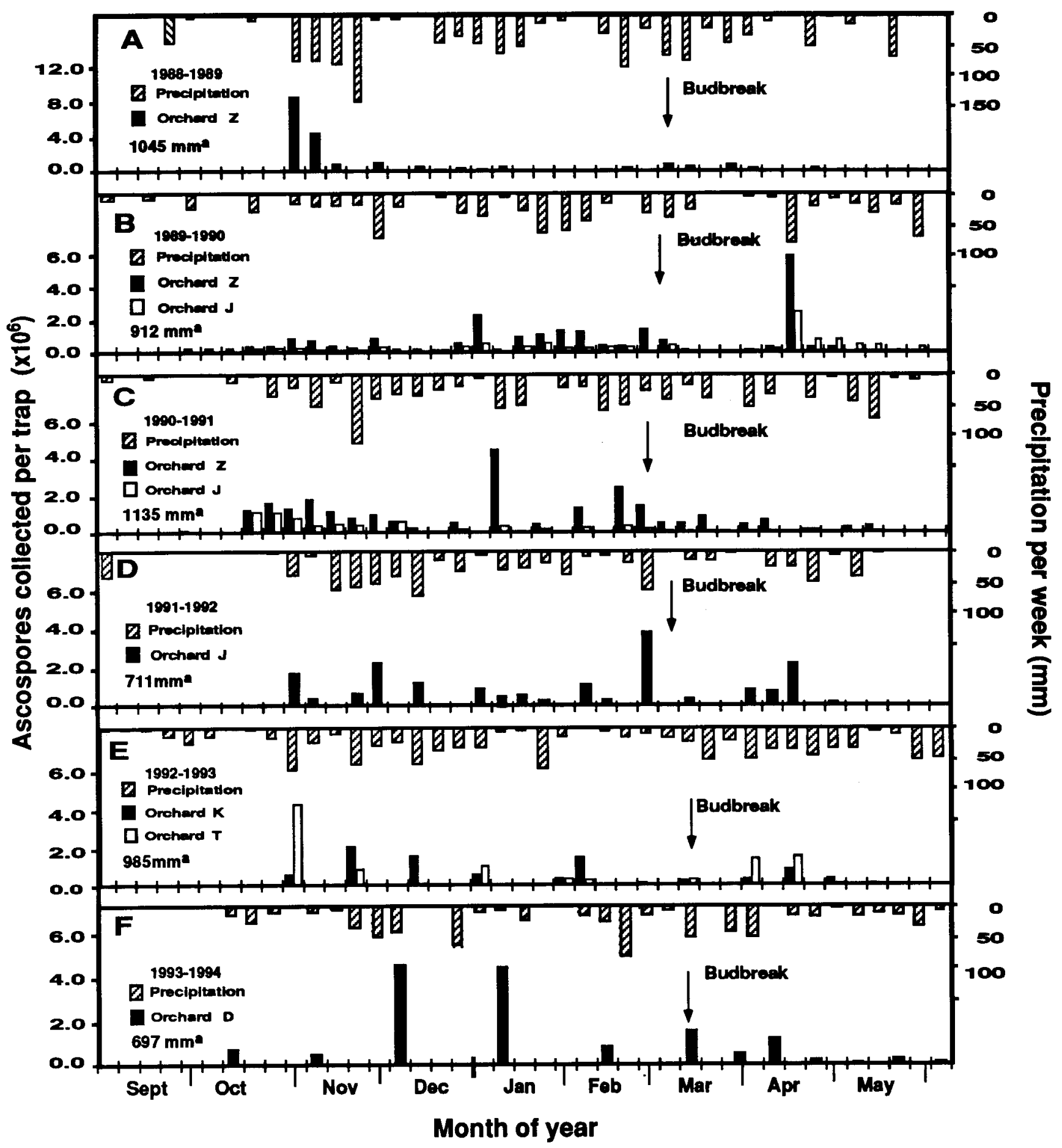

Fig. 4. Amount of precipitation (hatched bars) and mean number of ascospores of Anisogramma anomala collected in rain catch-type spore traps (black bars) from September to June in diseased European hazelnut orchards located in Multnomah and Clackamas counties, OR. The spore traps were positioned under sporulating cankers on branches of hazelnut cultivar Barcelona with the collection reservoir replaced every 1 to 4 weeks. Budbreak, when European hazelnut becomes susceptible to infection by $A$. anomala, is indicated by the arrow in each panel. Total cumulative precipitation recorded is indicated for each season. Orchards were sampled in A, 1988-1989; B, 1989-1990; C, 1990-1991; D, 1991-1992; E, 1992-1993; and F, 1993-1994. 
from all years resulted in a significant nonlinear model $(P>0.01)$ (Fig. 8), as did regression of $A_{\text {cum }}$ on the cumulative hours of precipitation $(P>0.01)$ (Fig. 5). No difference $(P>0.05)$ between the values of $A_{\text {cum }}$ observed in mist chambers and the expected values derived from the spore release data collected in the field was apparent (Fig. 5), based on a chi-square test.

For selected times during March and April, differences between the modeled and observed values of $A_{\text {cum }}$ were relatively small during most seasons, except for the differences based on data from 1989-1990 when large ascospore releases occurred in late April (Fig. 4). Exclusion of the 1989-1990 data from the comparison resulted in a model for which the mean percent difference between the actual and predicted cumulative proportion of the seasonal ascospore total was $<2.4 \%$ during the 8 weeks in spring when the trees are most susceptible to infection by A. anomala (Table 2). During the winter and spring of 1989-1990, most precipitation accumulated during storms of less than $7 \mathrm{~h}$ in duration, a condition that was not conducive for the release of ascospores of A. anomala (18). As a result, most ascospores were released during the first major storms in late April, later than the model predicted.

\section{DISCUSSION}

In a detailed description of the development of the ascostromata and perithecia of $A$. anomala in hazelnut tissue, Gottwald and Cameron (6) reported that asci were produced until the perithecia ceased expanding within the stromatic locules and that, at maturity, perithecia were characterized as having walls composed of dark, hardened, pseudosclerenchymatous cells. Based on these observations, our phenological data on stromal development indicated that most perithecia were mature by early winter under Oregon condi-

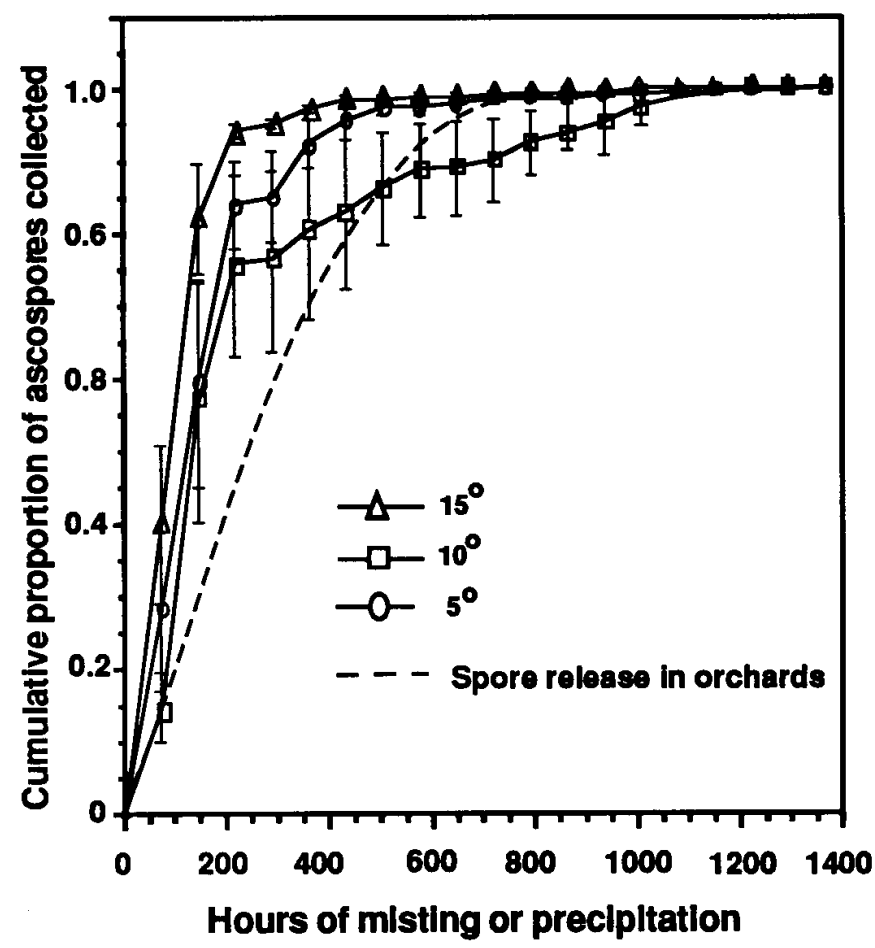

Fig. 5. Effects of temperature on the cumulative proportion of ascospores of Anisogramma anomala released from detached hazelnut branches under conditions of continuous branch wetness. The diseased branches were misted for $15 \mathrm{~s}$ every $30 \mathrm{~min}$ over a period of $1,850 \mathrm{~h}$ in chambers maintained at 5,10 , and $15^{\circ} \mathrm{C}$. Ascospores were collected in misted water that had run across the branch surface, with the collection reservoir replaced every $72 \mathrm{~h}$. The dashed line represents a regression relationship between the cumulative proportion of the seasonal ascospore total and the cumulative hours of precipitation derived from rain catch-type spore traps placed in European hazelnut orchards from September 1988 to June 1994: $y=1.2208(1-e)^{-0.001854 x}$. tions. At this time, perithecia contained the greatest number of ascospores, with most $(>90 \%)$ of these spores appearing to be mature. The proportion of mature ascospores remaining in perithecia varied little from January to May, after which time nearly all ascospores had been released. Coincident with perithecial maturation, the germination rate of ascospores increased through autumn and then plateaued at about $45 \%$ through winter and spring. This maximum rate of germination is low compared with that of some ascomycetous plant pathogens, but was consistent with the rates reported in a previous study concerned with this pathogen (24). An important observation of this study is that, unlike many other ascomycetous plant pathogens in which the ascospores mature during periods when the host is susceptible to infection $(5,13,15$, $25,27)$, the process of maturation and release of ascospores of $A$. anomala in western Oregon is ill-timed phenologically compared with the period when hazelnut is susceptible to infection.

In this study, a perithecium from the highly susceptible cultivar Ennis contained about twice as many ascospores as a perithecium from the moderately susceptible cultivar Barcelona. Gottwald and Cameron (6) reported the numbers of ascospores per perithecia comparable to those we observed for 'Ennis', but did not report from which cultivar his perithecia were obtained. It is possible that larger perithecia, on average, are produced in the cankers formed on 'Ennis', which tend to be larger and more rapidly expanding than those on 'Barcelona' (J. N. Pinkerton, unpublished data). Comparisons of perithecium size between the two cultivars, however, were not made in this study.

The analysis of the field data showed that a cumulative measure of precipitation (amount or hours) was the environmental variable most strongly correlated with the cumulative number of released ascospores. This result was consistent with our previous study in

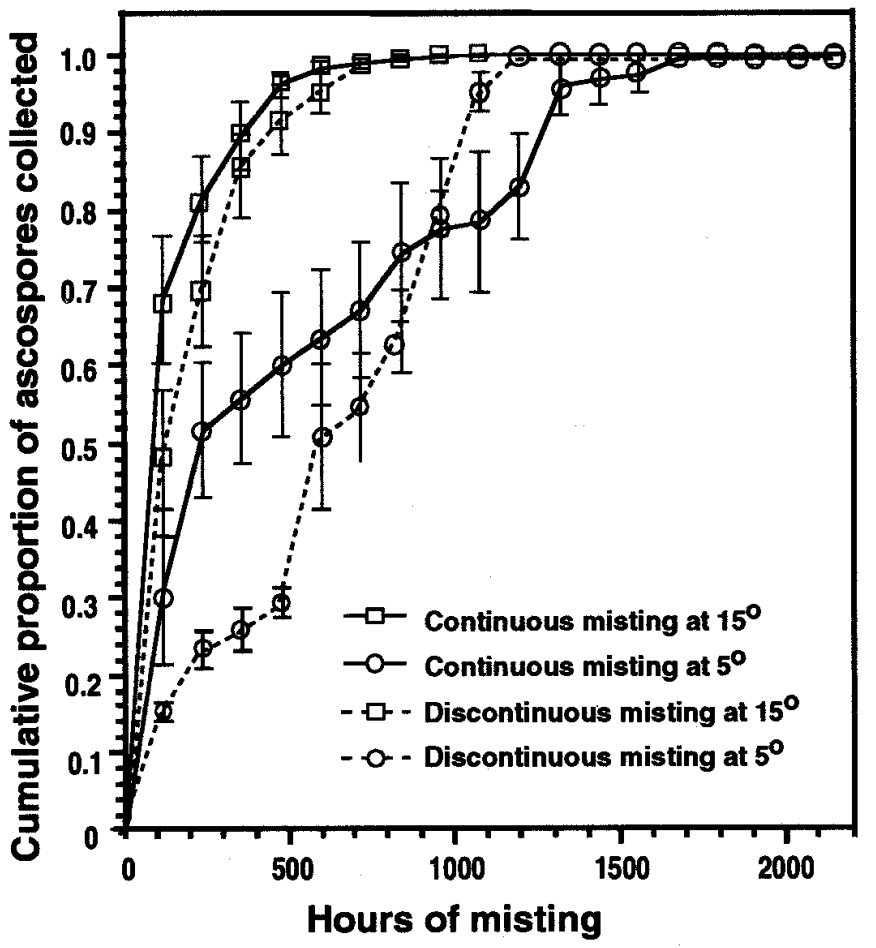

Fig. 6. Effects of temperature and wetting treatments on the cumulative proportion of ascospores of Anisogramma anomala released from detached hazelnut branches placed in mist chambers. For the continuous-wetness treatments, the diseased branches were misted for $15 \mathrm{~s}$ every 30 min over a period of 2,400 h; the discontinuous-wetting treatments were imposed by alternating the continuous-wetting treatment with no misting every 5 days for a total of $1,200 \mathrm{~h}$ of wetness. Temperature treatments were 5 and $15^{\circ} \mathrm{C}$. Ascospores released into misted water were collected in bottles that were replaced every $120 \mathrm{~h}$. Data shown for the discontinuous-wetting treatment represent only the wet hours of the wet/dry cycle; no spores were collected when the branches were dry. 
which the likelihood and intensity of ascospores released during the months of March and April were found to be principally a function of the duration of a precipitation event, but not of temperature (18). By contrast, the mist chamber experiments presented in this paper show that temperature also influences the rate of cumulative ascospore release. We interpret these results by consider-

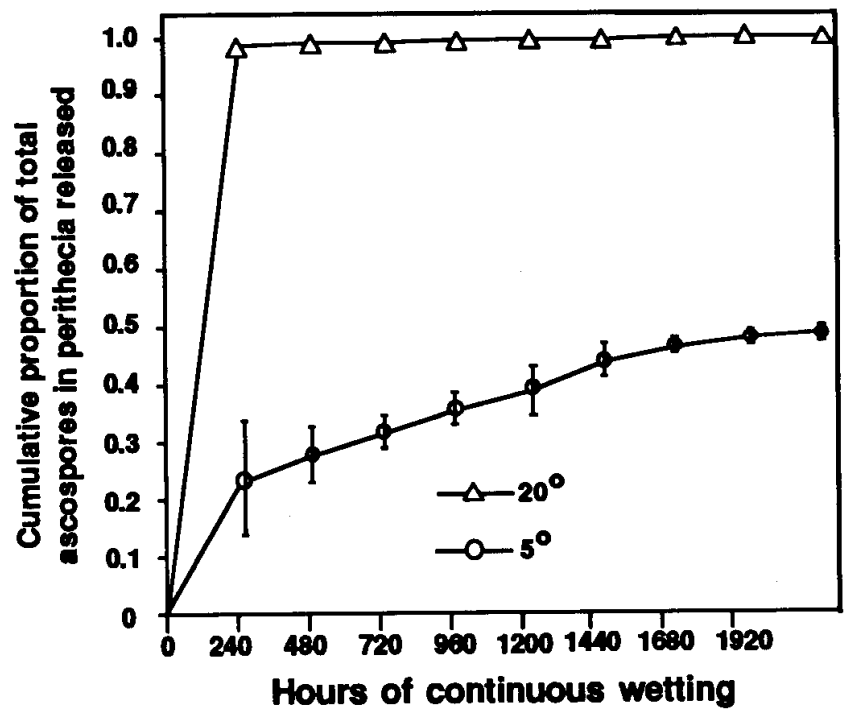

Fig. 7. Effects of temperature on the cumulative proportion of ascospores of Anisogramma anomala released from diseased hazelnut branches attached to potted, 2-year-old hazelnut trees placed in mist chambers held at 5 and $20^{\circ} \mathrm{C}$. Mist was applied to trees for $15 \mathrm{~s}$ every $30 \mathrm{~min}$ over a period of 2,160 h. The number of ascospores per perithecia was determined at the beginning and at the end of the misting period. Ascospores released into misted water were collected in bottles that were replaced every $240 \mathrm{~h}$. Vertical bars denote standard deviation. ing separately the process of perithecial maturation, which occurs in autumn, from the longer period of ascospore release. For example, in the mist chamber experiments, the diseased plant material used in the studies was collected in November, when less than half of the asci in perithecia were morphologically mature. In vitro studies (17) have demonstrated that the growth rate of hyphae of A. anomala increases linearly from a threshold of $5^{\circ} \mathrm{C}$ to an optimum of $21^{\circ} \mathrm{C}$. By analogy, the higher rate of release and total number of spores collected from cankers on detached branches at $15^{\circ} \mathrm{C}$ compared with $5^{\circ} \mathrm{C}$ was likely due to the differential effects of temperature on the rate of perithecial maturation $(4,9,21)$. Similarly, for the mist experiments with cankers on potted trees, $>97 \%$ of the ascospores were released from stromata on trees in $240 \mathrm{~h}$ of misting at $20^{\circ} \mathrm{C}$ compared with $<50 \%$ of the ascospores released after $2,160 \mathrm{~h}$ at $5^{\circ} \mathrm{C}$. This interpretation is also supported by comparison of field values of $A_{\text {cum }}$ among seasons. By the third week of November, for example, the total cumulative degree-days in autumn of 1988 was more than 100 units $(>15 \%)$ ahead of the other five

TABLE 1. Cross-correlation coefficients for cumulative precipitation variables, cumulative degree-days, and cumulative proportion of ascospores of Anisogramma anomala collected in rain catch-type spore traps that were placed under diseased hazelnut branches in western Oregon from September to June in 1988 to 1994

\begin{tabular}{|c|c|c|c|}
\hline $\begin{array}{l}\text { Cumulative } \\
\text { proportion of } \\
\text { total spores }\end{array}$ & $\begin{array}{c}\text { Arsine } \sqrt{ } x \\
\text { cumulative } \\
\text { proportion of } \\
\text { total spores }\end{array}$ & $\begin{array}{l}\text { Cumulative } \\
\text { precipitation } \\
(\mathrm{mm})\end{array}$ & $\begin{array}{l}\text { Cumulative } \\
\text { hours of } \\
\text { precipitation }\end{array}$ \\
\hline
\end{tabular}

\begin{tabular}{lllll}
\hline $\begin{array}{c}\text { Cumulative amount of } \\
\text { precipitation (mm) } \\
\begin{array}{c}\text { Cumulative hours of } \\
\text { precipitation }\end{array}\end{array}$ & 0.920 & 0.935 & & \\
$\begin{array}{c}\text { Cumulative degree- } \\
\text { days (base } 5^{\circ} \mathrm{C} \text { ) }\end{array}$ & 0.913 & 0.925 & 0.973 & \\
\hline
\end{tabular}

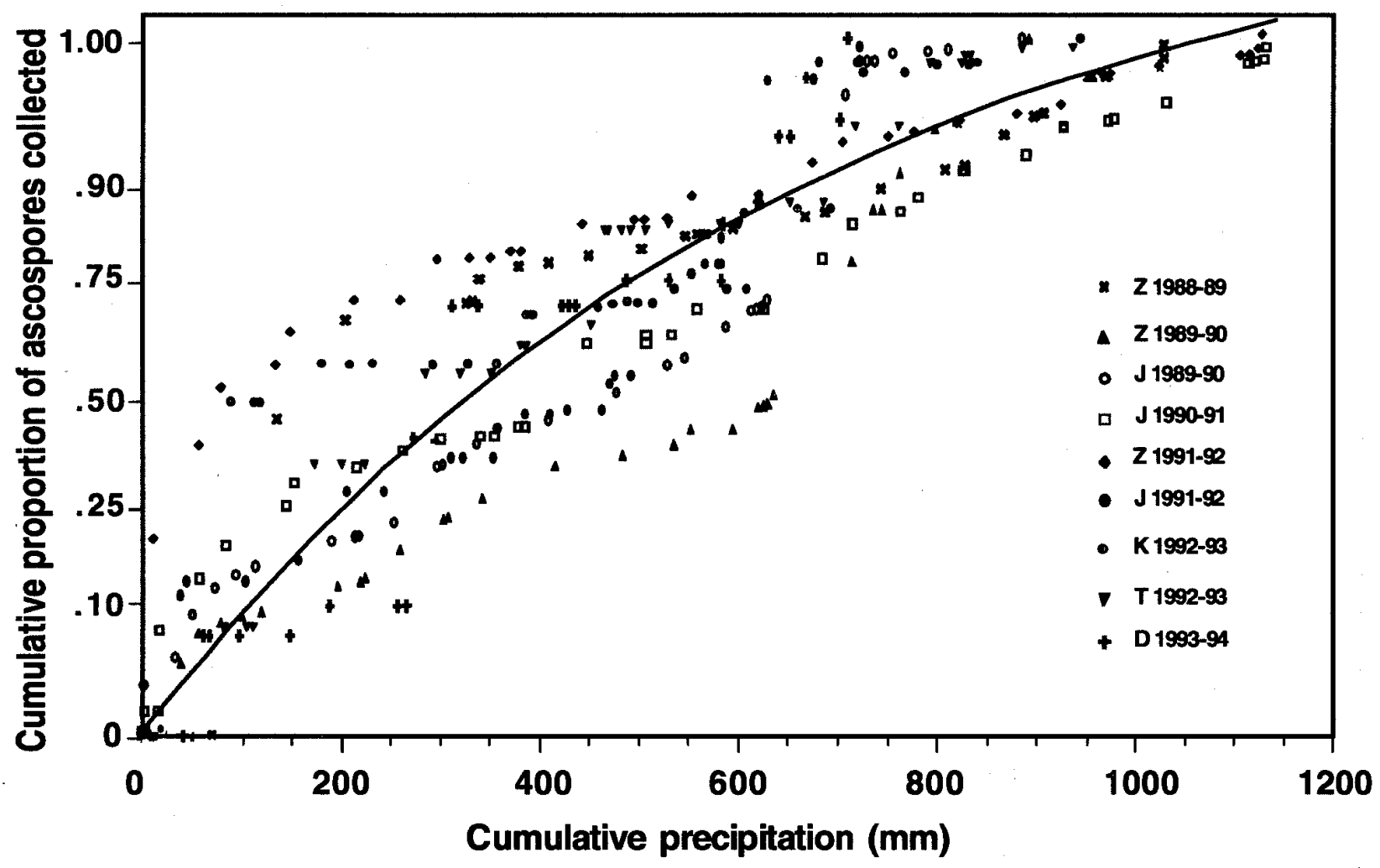

Fig. 8. Relationship between the cumulative amount of precipitation and the cumulative proportion of the seasonal total of ascospores of Anisogramma anomala collected in rain catch-type spore traps positioned under diseased hazelnut branches from September to June in 1988 to 1994 . The ascospores were collected in five hazelnut orchards (designated by letter preceding the season) located in Clackamas (D, J, K, and T) and Multnomah (Z) counties, OR. Values of the cumulative proportion of the seasonal ascospore total were arcsine $\sqrt{ } x$ transformed prior to regression analysis. The equation for the line is $y=2.0513(1-e)^{-0.00137 x}$. 
seasons. Correspondingly, the value of $A_{\text {cum }}$ in November 1988 also was 20 to $61 \%$ greater than the values of this variable obtained in the other years.

Although the inherent lack of independence of individual observations in a cumulative time series can create biased estimates of correlation coefficients when two time series are compared, we believe that the relationship between cumulative precipitation and cumulative ascospore release may still be useful for predicting qualitatively the potential risk for infection and spread of eastern filbert blight within specific seasons. Ascospores of A. anomala, once released, survive for only a few days (11). Thus, only those ascospores released near budbreak, or after leaves and shoots have begun to grow, can cause new infections in hazelnut trees $(11,23)$. Ascospores of $A$. anomala are also relatively inefficient at establishing infections, requiring an inoculum concentration of approximately $10^{5}$ spores per $\mathrm{ml}$ to infect a shoot reliably (11). Therefore, the probability of infection by A. anomala and spread of eastern filbert blight should be greatest in years with large numbers of ascospores remaining in perithecia after budbreak. For example, for the 1988-1989 and 1990-1991 seasons, <8\% of the seasonal ascospore total remained to be released after budbreak; in contrast, for 1989-1990, 1991-1992, 1992-1993, and 1993-1994, the model predicted that 16 to $27 \%$ of ascospores remained to be released. One use of such information is to help growers decide when the risk of new infection by A. anomala has become too low to warrant additional fungicide applications. In western Oregon, current recommendations for the control of eastern filbert blight are to apply fungicides at 2-week intervals from budbreak through mid-April $(10,11)$. Over the last 9 years, chemical control experiments, in combination with measured patterns of ascospore release, have indicated that between two and four fungicide applications are needed each year to provide a high degree of disease suppression. In orchards with a significant amount of eastern filbert blight, it is likely that three or four fungicide applications will be needed each season to obtain satisfactory disease control. In orchards or areas with few infected trees, however, our regression model may allow growers to use cumulative rainfall data to assess the proportion of ascospores remaining in perithecia and, therefore, determine if fungicide applications during the latter portion of the period of susceptibility (i.e., mid- to late April) are warranted. In the future, another use of the phenology data presented in this paper will be to assess the relative amount of adaptation that has occurred in A. anomala to the environmental conditions of the Pacific Northwest.

Eastern filbert blight has been present in the Pacific Northwest for only 30 years, and as a consequence, the biology of ascospore maturation and release in $A$. anomala may be only partially adapted to the region. The isolates of $A$. anomala currently in Oregon and Washington are thought to have originated from northeastern North America, where this pathogen is endemic on Corylus americanum. Autumns and winters in northeastern North America are generally colder and drier than those in western Oregon, and thus, within its native region, the phenology of perithecial maturation and ascospore release may coincide more closely with the emergence of hazelnut shoots in spring. For western Oregon, the relatively poor timing of ascospore release by A. anomala would appear to create at least some selection pressure on the pathogen to adapt its spore release to more closely match the phenology of the host. How quickly such an adaptation may occur is a matter of speculation, but there is some evidence that ascomycetous plant pathogens can adapt the timing of spore release to phenology of the host. For example, Lehman and Oudemans (14) reported recently that apothecial formation in isolates of Monilinia vaccinii-corymbosi were correlated with the timing of budbreak in the blueberry cultivars from which they were isolated. Over time, such an adaptation could also occur within $A$. anomala. In fact, the intensity of the selection pressure will likely increase as the hazelnut industry shifts from highly susceptible cultivars to cultivars that possess a greater resistance to eastern filbert blight.

\section{ACKNOWLEDGMENTS}

Research supported, in part, by the USDA Agricultural Research Service and Oregon Agricultural Experiment Station Specific Cooperative Agreement no. 58-5358-190 and by the Oregon Hazelnut Commission.

\section{LITERATURE CITED}

1. Bertrand, P. F., and English, H. 1976. Release and dispersal of conidia and ascospores of Valsa leucostoma. Phytopathology 66:987-991.

2. Davison, A. D., and Davidson, R. M., Jr. 1973. Apioporthe and Monchaetia cankers reported in western Washington. Plant Dis. Rep. 57:522-523.

3. Gadoury, D. M., and MacHardy, W. E. 1982. Preparation and interpretation of squash mounts of pseudothecia of Venturia inaequalis. Phytopathology 72:92-95.

TABLE 2. Comparison between the actual and predicted cumulative proportion of ascospore of Anisogramma anomala collected in hazelnut orchards in the northern Willamette Valley of Oregon at budbreak and during the following 8 weeks in the springs of 1989 to 1994

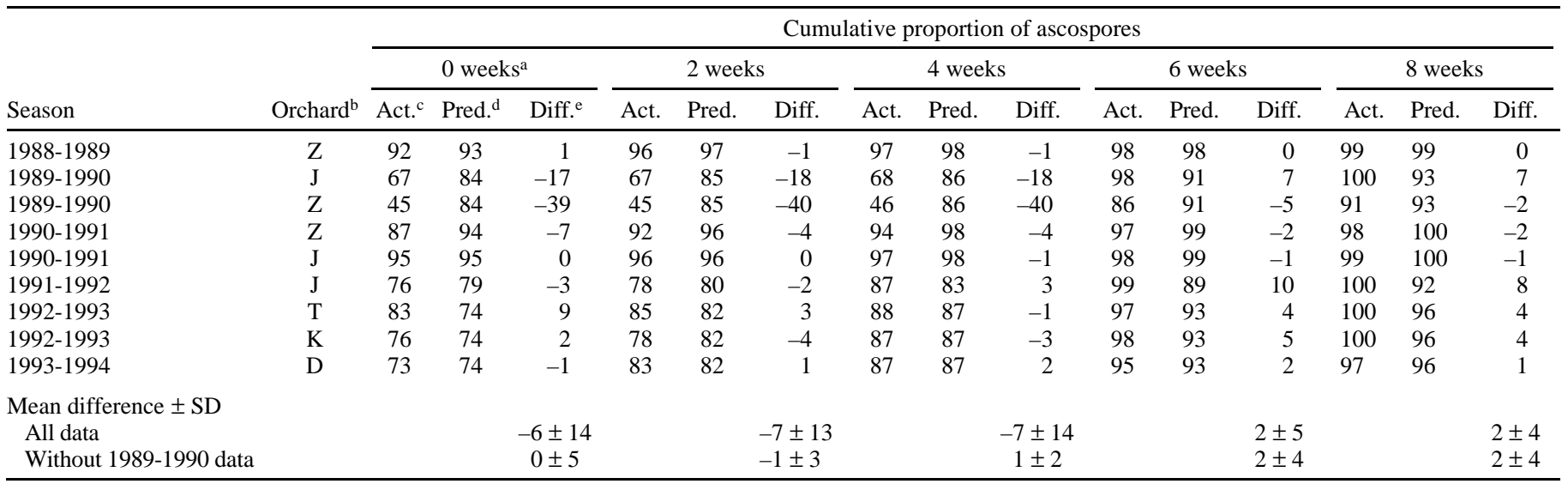

${ }^{a}$ Weeks after hazelnut budbreak. Budbreak, which occurs in early to mid-March, is when hazelnut becomes susceptible to infection by A. anomala .

${ }^{\mathrm{b}}$ Orchard Z was located in Multnomah County, OR, and the other orchards were located in Clackamas County, OR.

c Actual (Act.) mean cumulative proportion the seasonal ascospore total collected in 5 to 10 rain catch-type traps placed under diseased branches in each orchard at each date.

d Predicted (Pred.) cumulative proportion of the seasonal ascospore total based on the function $y=2.0513(1-e)^{-0.00137 x}$, in which $x$ is the cumulative amount of precipitation $(\mathrm{mm})$ recorded from 15 September to the date of the prediction, $y$ is the predicted proportion of spores collected from 15 September to the date of the prediction (Fig. 8).

${ }^{\mathrm{e}}$ Diff. $=$ difference between the actual and predicted cumulative proportion of ascospores collected. 
4. Gadoury, D. M., Seem, R. C., Rosenberger, D. A., Wilcox, W. F., MacHardy, W. E., and Berkett, L. P. 1992. Disparity between morphological maturity of ascospores and physiological maturity of asci in Venturia inaequalis. Plant Dis. 76:277-282.

5. Garcia, S. M., and Jones, A. L. 1993. Influence of temperature on apothecial development and ascospore discharge by Blumeriella jaapii. Plant Dis. 77:776-779.

6. Gottwald, T. R., and Cameron, H. R. 1979. Morphology and life history of Anisogramma anomala. Mycologia 71:1107-1126.

7. Gottwald, T. R., and Cameron, H. R. 1980. Infection site, infection period, and latent period of canker caused by Anisogramma anomala in European filbert. Phytopathology 70:1083-1087.

8. Gottwald, T. R., and Cameron, H. R. 1980. Disease increase and the dynamics of spread of canker caused by Anisogramma anomala in European filbert in the Pacific Northwest. Phytopathology 70:1087-1092.

9. James, J. R., and Sutton, T. B. 1982. Environmental factors influencing pseudothecial development and ascospore maturation of Venturia inaequalis. Phytopathology 72:1073-1080.

10. Johnson, K. B., Mehlenbacher, S. A., Stone, J. K., Pscheidt, J. W., and Pinkerton, J. N. 1996. Eastern filbert blight of European hazelnut: It's becoming a manageable disease. Plant Dis. 80:1308-1316.

11. Johnson, K. B., Pinkerton, J. N., Gaudreault, S. M., and Stone, J. K. 1994. Infection of European hazelnut by Anisogramma anomala: Site of infection and effect of host developmental stage. Phytopathology 84:1465-1470.

12. Johnson, K. B., Pscheidt, J. W., and Pinkerton, J. N. 1993. Evaluation of chlorothalonil, fenarimol, and flusilazole for control of eastern filbert blight. Plant Dis. 77:831-837.

13. Latorre, B. A., Yañez, P., and Rauld, E. 1985. Factors affecting release of ascospores by the pear scab fungus (Venturia pirina). Plant Dis. 69:213-216.

14. Lehman, J. S., and Oudemans, P. V. 1997. Phenology of apothecium production in population of Monilinia vaccinii-corymbosi from earlyand late-maturing blueberry cultivars. Phytopathology 87:218-223.

15. Luley, C. J., and McNabb, H. S., Jr. 1989. Ascospore production, release, germination, and infection of Populus by Mycosphaerella populorum.
Phytopathology 79:1013-1018.

16. Pinkerton, J. N., Johnson, K. B., Mehlenbacher, S. A., and Pscheidt, J. W. 1993. Susceptibility of European hazelnut clones to eastern filbert blight. Plant Dis. 77:261-266.

17. Pinkerton, J. N., Johnson, K. B., Nelson, S. J., and Stone, J. K. 1992. Influence of temperature in vitro and in planta on Anisogramma anomala, the cause of eastern filbert blight. (Abstr.) Phytopathology 82:1132.

18. Pinkerton, J. N., Johnson, K. B., Stone, J. K., and Ivors, K. L. 1998. Factors affecting the release of ascospores of Anisogramma anomala. Phytopathology 88:122-128.

19. Pinkerton, J. N., Johnson, K. B., Theiling, K. M., and Griesbach, J. A. 1992. Distribution and characteristics of the eastern filbert blight epidemic in western Oregon. Plant Dis. 76:1179-1182.

20. Pinkerton, J. N., Stone, J. K., Nelson, S. J., and Johnson, K. B. 1995. Infection of European hazelnut by Anisogramma anomala: Ascospore adhesion, mode of penetration of immature shoots, and host response. Phytopathology 85:1260-1268.

21. Spotts, R. A., and Cervantes, L. A. 1994. Factors affecting maturation and release of ascospores of Venturia pirina in Oregon. Phytopathology 84:260-264.

22. Spurr, A. R. 1969. A low-viscosity, epoxy-resin embedding medium for electron microscopy. J. Ultrastruct. Res. 26:31.

23. Stone, J. K., Johnson, K. B., Pinkerton, J. N., and Pscheidt, J. W. 1992. Natural infection period and susceptibility of vegetative seedlings of European hazelnut to Anisogramma anomala. Plant Dis. 76:348-352.

24. Stone, J. K., Pinkerton, J. N., and Johnson, K. B. 1994. Axenic culture of Anisogramma anomala: Evidence for self-inhibition of ascospore germination and colony growth. Mycologia 86:674-683.

25. Sutton, T. B. 1981. Production and dispersal of ascospores and conidia by Physalospora obtusa and Botryosphaeria dothidea in apple orchards. Phytopathology 71:584-589.

26. Szkolnik, M. 1969. Maturation and discharge of ascospores of Venturia inaequalis. Plant Dis. Rep. 53:534-537.

27. Tate, K. G. 1979. Sclerotinia ticola ascospore fluctuations in a peach orchard during bloom. N.Z. J. Agric. Res. 22:355-360. 